\title{
Closing in on Genes for Manic-Depressive Illness and Schizophrenia
}

\author{
Elliot S. Gershon, M.D., Judith A. Badner, M.D., Ph.D., Lynn R. Goldin, Ph.D., \\ Alan R. Sanders, M.D., Anibal Cravchik, M.D., Ph.D., and Sevilla D. Detera-Wadleigh, Ph.D.
}

Advances in the human genetic map, and in genetic analysis of linkage and association in complex inheritance traits, have led to genetic progress in the major psychoses. For chromosome 6 in schizophrenia, and chromosomes 18 and 21 in manic-depressive illness, there are reports of linkage in several independent data sets. These are small effect genes, best detected with affected-relative-pair linkage methods. Association with candidate genes is an alternative strategy to uncovering susceptibility genes for these illnesses, but convincing associations remain to be demonstrated. New clinical and laboratory investigation methods are being developed. Testing every gene in the human genome for association with illness has recently been proposed (Risch and Merikangas 1996). This would require further progress in characterizing the genome and in automated large-scale genotyping. The best type of pedigree sampling for common disease studies, whether for linkage or association, is not yet established. An endophenotype hybrid strategy can combine genetic linkage, association, and pathophysiologic studies. As clinical molecular investigation methods advance, identification of disease susceptibility mutations and delineation of their pathophysiological roles may be expected.

[Neuropsychopharmacology 18:233-242, 1998]

Published by Elsevier Science Inc.
KEY WORDS: Genetics; Bipolar illness; Depressive disorder; Schizophrenia; Genetic linkage; Genotypes; Linkage disequilibrium; Dopamine receptors; Chromosome 6; Chromosome 18; Chromosome 21; Event-related potentials

The major goal of molecular research in psychiatric illness is to identify mutations that confer susceptibility to illness and have understandable pathophysiological effects. We do not propose in this paper to resolve whether we have reached this point-we have not-but to determine whether any findings thus far have advanced us toward this goal, and what more is needed. Mutations that

From the Clinical Neurogenetics Branch, National Institute of Mental Health, Bethesda, Maryland.

Address correspondence to: Dr. Elliot S. Gershon, Chief, Clinical Neurogenetics Branch, National Institute of Mental Health, Building 10, Room 3N218, National Institutes of Health, Bethesda, MD 20892-1274.

Received April 24, 1997; revised July 15, 1997; accepted July 22, affect many functional aspects of the central nervous system, including normal behavioral variation and variation in response to specific therapies of illness, are also subsumed within the goals of psychiatric genetics.

\section{TWO STRATEGIES: GENOME SCANNING AND CANDIDATE GENES}

The term "reverse genetics" is no longer current, having been replaced by "genome scanning" and "positional cloning." For many investigators, genome scanning remains the reverse of the sensible strategy for detecting biologically important derangements, which would be to start from discovery of a protein or other molecule involved in a biological process, followed by cloning its gene. Genes discovered in this way may become candidate genes for illness. However, genome scanning proceeds by testing of each chromosomal segment (or the mitochondrial genome) for cotransmission with illness 
within families, a most indirect approach to biology. Nonetheless, genome scanning has led to many discoveries of disease genes that would not have been discovered otherwise (at least not in our time), including neuropsychiatric disease (LaSpada et al. 1994; McKusick 1994; Cooper and Schmidtke 1992).

Each strategy has its advantages. The major strength of genome scanning is that it covers all possible biological mechanisms of inherited disease, including possibilities that the investigator has not thought of and might not come to in a lifetime of work. Discovery of expanding trinucleotide repeats as a cause of disease, first discovered in Fragile- $X$ mental retardation, for example, was completely unanticipated, and the biological role of many genes that cause disease in this way still remains to be discovered (Ross et al. 1993). The strength of the candidate gene strategy is its directness. A hypothesis that a particular gene is involved in pathophysiology includes the disease mechanism. If a mutation is present, the biology of disease can be elucidated rapidly.

Genetic linkage to illness is present when ill relatives share alleles at one or several genetic loci, but at any linked locus, the shared allele need not be the same in different families. Linkage is the currently used strategy for genome scans (Lander and Schork 1994). Although a candidate gene hypothesis can be studied by linkage within a family or series of families, the more direct test is association. In association, a particular allele or mutation in the candidate gene is found more often in patients than controls (less often if it is a protective allele). It should be noted that matching unrelated patients and controls is hazardous, because of unknown population stratifications. The currently favored method of testing for association is within-families comparison of transmitted versus nontransmitted alleles (Lander and Schork 1994; Spielman and Ewens 1996). That is, in a series of families a specific allele is more consistently transmitted from parents to ill offspring than would be expected by chance.

In bipolar illness and schizophrenia, there is a host of plausible candidate genes, many based on neuropharmacology of treatment, without direct biological supporting evidence. Significance testing of a result by an observed $p$-value in a study of one such gene must be corrected for by taking into account the very large number of genes that could have been tested (Risch and Merikangas 1996; Crowe 1993) or by testing and replication in several independent series to generate a single result. It is misleading to test association with one gene, such as one of the dopamine receptor genes in schizophrenia, using a nominal $p$-value of .05 as the significance threshold. Unique reasons for testing a particular gene can always be advanced, such as the affinity of clozapine for the $\mathrm{D}_{4}$ dopamine receptor. Nonetheless, we believe the investigator in such a study should remind him or herself that the number of potential candidates includes all the genes that interact with the cellular sig- nal reception and transduction systems affected by any of the psychotropic drugs useful in an illness. This interaction can be direct or indirect (downstream in a cascade of signal transduction events, for example). Any of these genes can have a case made that it is a candidate gene. Because there are 30,000 to 50,000 genes expressed in the brain, the number of plausible candidates may be as large as a thousand or more genes (one gene family of interest, G-protein-coupled receptors, has a thousand members, for example).

The threshold of significance should thus not be a nominal $p$-value $<.05$. To get less than a .05 probability that the observation is a false-positive, the threshold for a significant observed $p$-value in a single association study should be set at .05 divided by the number of genes which might just as reasonably have been considered. For 1,000 candidate genes, the threshold for significance would be $.05 / 1000$ or .00005 . Furthermore, following a demonstration of association with a polymorphism for a candidate gene derived from a biological hypothesis, the candidate hypothesis should be supported directly by demonstration of an associated mutation that changes the function of the candidate gene. This is a set of standards that has yet to be met in manic-depressive illness and schizophrenia, but adopting it might be prudent and protect the field from false-positives. It would be analogous to the criteria adopted for linkage, to protect against false-positives in genome scans.

A statistical solution to the multiple genes problem in association studies has been developed by Risch and Merikangas (1996), who propose that association be used as a genome-scanning strategy, with significance tests that take into account all the genes in the genome, and the number of polymorphisms tested in each gene. They show that a genomic within-family association scan has greater power (smaller sample size needed) than a genomic linkage scan to detect genes of small effect. Small effect genes in their analysis are those with a genotypic relative risk (GRR; increased chance that an individual with a particular genotype has disease) between 2 and 4. (GRR of 2 corresponds in some instances to a locus-specific recurrence risk $\left(\lambda_{5}\right)$ of 1.3 (Scott et al. 1997).) This strategy is not yet implementable, because of incomplete knowledge of the human genome. The pivotal assumption that disequilibrium will generally exist with polymorphisms of disease loci remains to be supported.

\section{CURRENT LINKAGE AND ASSOCIATION FINDINGS IN BIPOLAR ILLNESS AND SCHIZOPHRENIA}

\section{Genetic Epidemiology of Diagnosis}

It is commonly asserted that unreliability or uncertainty in phenotypic definition is a unique problem for molec- 
ular study of psychiatric illnesses, and that valid findings are therefore unlikely. This is a compounding of several misconceptions about disease definition and about complex inheritance disorders. Many common inherited disorders, such as dementia associated with aging, or malignant melanoma/displastic nevus syndrome, have phenotypes that are continuous with normally observed variation, and about which expert diagnosticians will disagree over many cases. This has not prevented the detection of linkage or association. What is needed for genetic study of any phenotype is the development of standardized and reliable phenotypic measurements, and their validation in epidemiologic studies, including coaggregation in families, twin, and adoption studies. For bipolar illness and schizophrenia, the validity of phenotype assignment has been amply demonstrated and reproduced in numerous geneticepidemiologic studies (Nurnberger Jr. et al. 1994; Gershon et al. 1982).

Detectability of individual susceptibility genes by a whole-genome linkage scan is a function of sample size, informativeness and density of markers, and the statistical role each susceptibility gene plays (in terms of increased risk of illness), as described by Risch (1990a,b). Certainly, there may be an aspect of a common disease phenotype which, if known, will greatly aid the detection of a particular susceptibility gene, such as early onset in Alzheimer's and in breast cancer. Phenotype definitions in these two disorders gave clear evidence for single major locus illness subtypes, by analysis of the distribution of illness in; the pedigrees that fit the definition. But this is not the only way to detect genes in complex illnesses. For genes of small effect, we are aware of no instance in which phenotypic redefinition, beyond the genetic-epidemiology based definition described above, was necessary for initial gene detection. Furthermore, testing many subdivisions of any data set increases the probability of false-positive results due to multiple tests.

By its distribution in families, schizophrenia is an example of complex inheritance, where the risk to relatives declines precipitously as the relationship becomes more distant. Using schizophrenia as an example, Risch (1990a) showed that with its observed familial risks schizophrenia could not be due to a single disease gene, even with reduced penetrance (not all persons with the disease gene become ill). He demonstrates that for a dominant or additive disease gene the risk should only decrease by (roughly) one-half as one progresses to each more distant class of relative, and that does not occur. For recessive inheritance, where a different pattern obtains, schizophrenia still does not fit. The observed risks do fit a pattern of oligogenic inheritance (interaction between a few genes, in this case two or three). These would be genes of small effect. As it turned out, the genes that have been reported and replicated in linkage stud- ies of manic-depressive illness and schizophrenia (Table 1) are genes of small effect.

\section{Linkage}

Studying sets of ill relatives (usually affected-sib-pairs) for concordance on genetic linkage markers (that is, for identity-by-descent) is a paradigm for genetic investigation of common diseases, which can detect genes with subtle effects (Weeks and Lange 1988; Suarez et al. 1978). It is now the preferred method of linkage detection (Lander and Schork 1994), although there is still debate over this among geneticists (Greenberg et al. 1996). Detectability depends on the magnitude of the risk imparted by a given locus and the size of the sample of families studied. It does not require correctly specifying parameters such as the frequency of the gene or the pattern of inheritance (dominant, recessive, etc.).

In a very large pedigree with many individuals affected with a common disease, multiple disease genes, due to marrying in, may have contributed. At the same time, if there is reduced penetrance (for a single-locus disorder), or several susceptibility genes, some gene carriers will not be ill. Under this circumstance, generally no single-locus model gives a uniquely best fit to the data. Because a model must be specified in traditional Lod score analyses, it may well be wrong. Events like these could invalidate an analysis based on a fully specified genetic model (such as a single recessive disease gene with a specified frequency and penetrance), which must apply to every ill and well individual in the pedigree. However, the affected-relative-pair methods are "model-free" or "parameter-free" (that is, they do not require the parameters of disease allele frequency and penetrances) and are more robust to complex inheritance events than other analytic methods. The advantage of this approach is that individual genes can be detected that are components of more complex patterns of inheritance. There are disadvantages as well. One disadvantage is loss of power; a larger number of ill relatives is needed than in traditional analysis, and the particular value of large pedigrees is lost (see below). Another disadvantage is that the chromosomal region to which linkage is found is very broad.

These nonparametric approaches have led to recent reports of genetic linkage to previously intractable common diseases, including schizophrenia and manicdepressive illness. What is different for this series of reports, as contrasted with earlier reports in psychiatry, is that some have been followed by replications. Table 1 includes published positive findings with significance thresholds recommended by Lander and Kruglyak (1995) for definite or suggestive linkage $\left(p<2.2 \times 10^{-5}\right.$ or $p<7.4 \times 10^{-4}$; thresholds are for affected-sib-pairs) with at least one confirmatory report at the significance threshold for replication $(p<.01)$. The significance 
Table 1. Linkage Findings Meeting Significance Criteria for Linkage or Probable Linkage with at Least One Replication

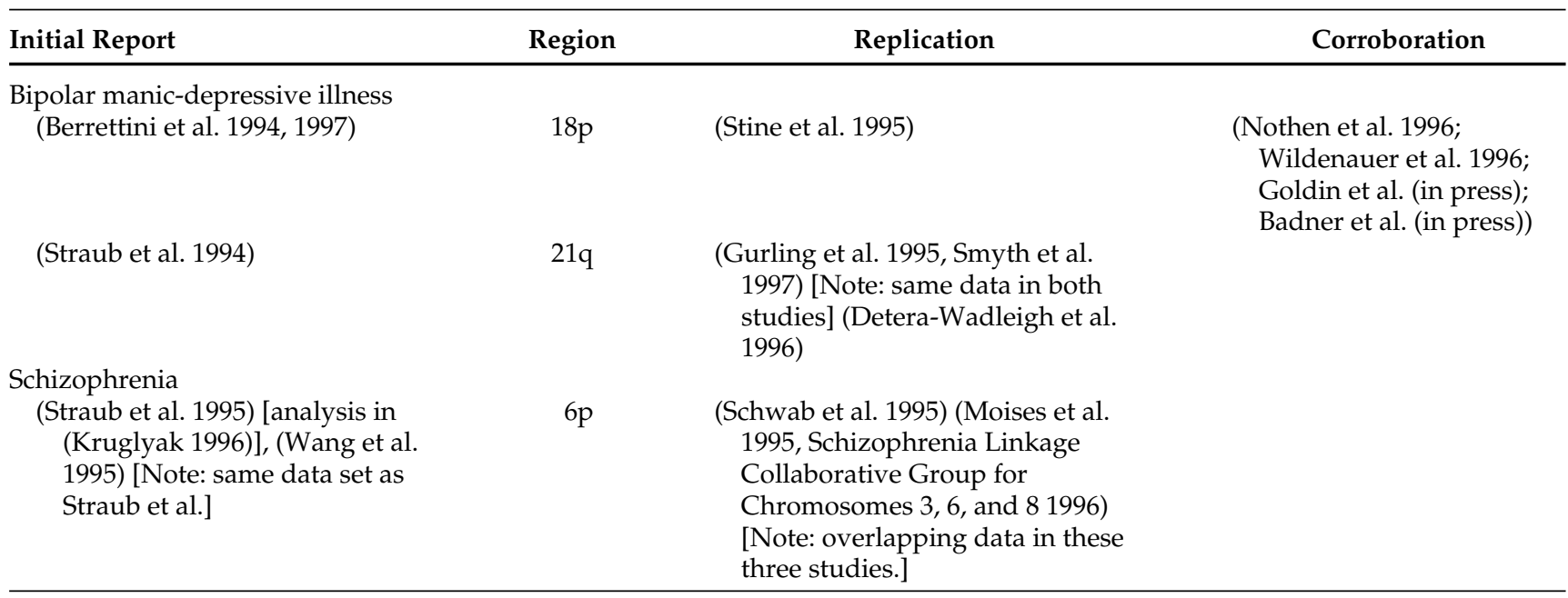

threshold for replication is less stringent because the probability of a false-positive in a genome-wide scan need not be accounted for. We include as "corroborative" studies that do not meet the significance criterion, or meet it only with some qualification of the phenotype definition. For example, Wildenauer et al. (1996) studied schizophrenia and related conditions in the families of schizophrenia probands, including recurrent major depression. They found suggestive linkage and association evidence in the same area of chromosome 18 as Berrettini et al. (1994), which implies that the phenotype related to this gene may be very inclusive.

By and large, the literature if full of controversy, but these results are the least controversial. There are several other reports that could arguably be included in Table 1 but were not included because of subthreshold significance levels, initial reports that later failed to replicate or be corroborated in the same families, controversy over map inconsistencies, significance levels obscured by excessive proliferation of models, or significant results obtained by post hoc sample subdivision (for bipolar illness see review in (Gershon, 1995), also (Stine et al. 1995; Freimer et al. 1996), for schizophrenia see review in (Schizophrenia Linkage Collaborative Group for Chromosomes 3, 6, and 8 1996). Other recent reports are too recent to have several attempts at replication published (Blackwood et al. 1996; Ginns et al. 1996).

Nonetheless, there is an uncomfortable number of nonreplications for the findings in Table 1, (Freimer et al. 1996; De Bruyn et al. 1996; Coon et al. 1996) as there are for small effects genes in other complex diseases, such as insulin-dependent diabetes mellitus (IDDM) and multiple sclerosis (Copeman et al. 1995; Bell and Lathrop 1996; Cordell and Todd 1995). It has been claimed that inconsistent replication is equivalent to no replication, and that these diseases may prove too complex to have disease genes detected by linkage (Risch and Botstein 1996). This claim is a conjecture, offered without logical or simulation support, albeit by scientists whose conjectures deserve consideration. However, there is a reasonable statistical explanation for the nonreplications. The susceptibility loci in Table 1 are small effects genes; for the chromosome 18p bipolar locus, we estimate the locus-specific risk $(\lambda)$ to be 1.4 to 2 . There is very little statistical power to detect this sort of linkage in the sample sizes commonly used (100 to 200 affected sib pairs [ASPs]). Even with the higher value of $\lambda$, a series of 100 ASPs has $15 \%$ power to detect linkage (in an interval mapping scan with a Lod score threshold of 3 for significance) (Hauser et al. 1996). With 200 ASPs, the power is $51 \%$. The literature can thus contain a mixed series of reports for a valid linkage. Vastly increasing sample sizes is one way to overcome this problem, and demonstration of a valid association (linkage disequilibrium) within the region is another.

A method for meta-analysis for modest-sized-series studies has yet to be developed (Rice 1997). Our own inclination is to accept results from modest-sized pedigree series (roughly 100 or more affected-sib-pairs) when there is a linkage detection and at least one independent replication, because the total number of such linkage studies is not so very large that the same region is likely to generate repeated false positive results. This is our own conjecture, however, and not a criterion based on rigorous statistical reasoning.

Current Issues in Linkage Sampling and Analysis for Common Diseases. Criteria for significance: Assumptions and studied choices underlie the current consensus on significance of linkage results, and active discussion and reworking of these issues are ongoing. Lander and Kruglyak's criteria (1995) for accepting and replicating linkage can be misread to be a true threshold, where a result just less significant than the threshold is to be considered differently from one marginally more significant (Elston 1997). Because the threshold is based 
on their computed $5 \%$ probability of finding a false-positive linkage to one locus in a genome-wide search, a reasonable but arbitrary choice, it is clear that a result that is marginally less significant is just that, and not to be rejected out of hand. The replication of schizophrenia linkage to $6 \mathrm{p}$ in Table 1 includes data (Schizophrenia Linkage Collaborative Group for Chromosomes 3, 6 , and 8 1996) which are marginally out of the significance criterion.

Another problem is the significance threshold for multilocus results, where currently an equivalent significance threshold is used to that for single-locus results (Risch 1990b; Kruglyak 1996). This is valid because, in both cases, the significance is based on a likelihood ratio calculated at a single point. However, as demonstrated by Goldin and Chase (1997) on simulated data, a less stringent significance level, if it extends over a few consecutive loci, gives the same power and rate of false-positives as the Lander and Kruglyak criteria (Lander and Kruglyak 1995).

Multiple overlapping diagnostic classifications are commonly used in complex disease genetic analyses. Because these are not independent categories, there is no obvious way to correct the significance threshold for testing multiple models. Investigators generally do not correct the significance threshold, but when they do not correct they will commonly restrict themselves to not more than two overlapping diagnostic classifications.

Pedigree selection: A genetic mechanism of a few small-effect susceptibility genes in common diseases implies that these genes have high population frequencies. As a result, in a large pedigree, even in a population isolate, distant relatives may have illness due to the same gene, but not inherited from the same ancestor. All the multigenerational analyses we now do are testing for IBD from a common ancestor. In a preliminary analysis of simulated data analyzed by the GENEHUNTER program (Kruglyak 1996), under disease allele frequencies of $5 \%$ and $50 \%$, we (Badner and Gershon, unpublished) have demonstrated that distantly related relatives (such as two pairs of sibs who are second cousins to each other) actually give less power to detect linkage to a marker locus as a single extended pedigree than they do if they are considered as two nuclear families (results not shown).

Genetic isolate populations: High disease allele frequency may be expected to be present in population isolates, as well. Thus, our conclusion on the reduced utility of greatly extended pedigrees applies, even though these pedigrees are more easily assembled in an isolate. One advantage of isolates remains that some susceptibility genes may be fixed at high frequencies, making the illness genetically simpler. Linkage disequilibrium (association) extends over very large distances, if the isolate is recently formed, which makes linkage more detectable by association with haplotypes (Houwen et al. 1994). Of course, the utility of disequilibrium in defining a very small region in which the gene must be found is lost in that situation.

Large linkage regions: These are commonly observed with small-effects genes (cf., Stine et al. 1995; Berrettini et al. 1994; Kruglyak and Lander 1995).) There is no efficient way to use recombinant individuals to narrow the region in which the disease gene may reside, because no relative is an unambiguous recombinant. Consider two relatives who share alleles at one locus, but not at the adjacent locus. One cannot be sure there is a recombination, because there is only a modest probability that the pair were identical by descent at a disease locus to begin with. This is quite different from a disease with a single major locus observed in a large pedigree.

Narrowing a linkage region to detect a disease gene, using linkage methods alone, will require extremely large samples, perhaps 3,000 affected-sib-pairs in the case of the affective disorders linkage on chromosome 18 described by Berrettini et al. in 1994 (Kruglyak and Lander 1995). An alternative method is suggested by the arguments of Risch and Merikangas (1996) on using association for whole genome scanning. If we were to scan for association at small intervals, only in the chromosomal region in which there is evidence for linkage, the number of tests performed in the scan would be much smaller than the one million tests in a whole genome scan for disequilibrium envisaged by Risch and Merikangas. The threshold for significance would be less stringent. The region could be efficiently sampled for linkage disequilibrium this way. For a pedigree series from a population that is not a recent isolate, this is an appealing strategy.

\section{Candidate Genes}

In the literature on major psychoses, the term candidate gene is often used to refer to a gene that is part of a biological system that is hypothesized to be disordered in illness, such as a dopamine receptor or transporter molecule abnormality. Generally, the term candidate should be reserved for a gene for which there is some direct supporting evidence, usually a gene in a chromosomal region in which linkage has been observed, or genes that can be related to a demonstrated pathophysiologic abnormality, or to an animal model of disease.

Candidate genes related to the processes of monamine synaptic transmission and signal transduction are directly appealing to the biological psychiatrist, because of the neuropharmacological bridge. This refers to the enormous utility for therapeutic drug development of the dopamine hypothesis of psychosis and the norepinephrine/serotonin/dopamine hypotheses of depression and anxiety. Acetylcholine, GABA, glycine, and aspartate/glutamate transmission systems have also generated candidate gene hypotheses. 
To evaluate these candidate gene studies, some methodological points should be raised. Testing a candidate gene hypothesis by linkage rather than association is not irrational, but this chooses the method with weaker statistical power (Risch and Merikangas 1996). On the other hand, one can have more confidence that the genomic region containing the gene is in fact scanned, and linkage is robust to the presence of multiple ancestral mutations.

Among association studies, within-family association studies are less subject to hidden population stratification than comparisons of patients versus controls (Spielman and Ewens 1996; Lander and Schork 1994). Depending on which molecular strategy is applied to a candidate gene, the results will have greater or lesser biological meaning. In association studies, testing a single polymorphism, such as length of a repeat sequence or a base-pair substitution, does not necessarily serve as a statistical scan of the entire gene (including the introns, intron/exon junctions, exons, and promoter region). For a single polymorphism to serve as a valid test of a mutation elsewhere in the gene, there would have to be demonstrated disequilibrium over several polymorphic sites that encompass the entire gene. Even when this is present, and the gene studied is in fact a susceptibility gene, disequilibrium of this set of sites with illness may not be observed, because of multiple ancestral disease mutations. At some point in the investigative process, whether to confirm an association or to rule out a gene as contributing, a direct scan of the gene for sequence variants must be done. This scan should encompass the entire genomic sequence of the gene (including expressed sequences, intron/exon junctions, promoter regions). The biological relevance of a detected variation must be determined through demonstration of functional differences between the gene variants.

In a brief review such as this, we cannot provide a comprehensive review of all candidate gene studies in the major psychiatric disorders. But a recapitulation of some of the work on dopamine receptor genes in schizophrenia may prove useful as an illustration of the current strengths and weaknesses of the candidate gene approach in many psychiatric disorders and as an update.

In 1963, Carlsson and Lindquist (1963) discovered the general principle that antipsychotic drugs block dopamine receptors. Blockade of these cell-surface receptors blocks the subsequent intracellular cascade of events, termed postsynaptic signal transduction. The derivative hypothesis of disturbed dopaminergic transmission as an etiologic event in schizophrenia has generated a great deal of research in the subsequent years (cf., Losonczy et al. 1987). There are now known to be two subfamiles of dopamine receptor genes, with different pharmacology, signal transcutions, and genomic organization. The $\mathrm{D}_{1}$-like subfamily includes $\mathrm{D}_{1}$ and $\mathrm{D}_{5}$, which couple to Gs proteins, whereas the $\mathrm{D}_{2}$-like sub- family $\left(D_{2}, D_{3}\right.$, and $\left.D_{4}\right)$ couple to Gi proteins (Gingrich and Caron 1993).

The dopamine receptor molecules on the synapse have been the most appealing candidate genes to investigators of disease susceptibility. These constitute the molecules with the largest number of candidate gene studies in schizophrenia found by us in a recent computerized literature search using MEDLINE (also reviewed: recent issues of Am. J. Med. Genet. (Neuropsychiat. Genet.) through February 1997). The molecules involved in post-receptor signal transduction events, such as subunits of heterotrimeric G-proteins, also represent plausible candidates for a dopamine-based hypothesis (Ram et al. 1997).

Among the association studies of these genes to date, only a few complete molecular scans of the entire gene have been performed (such as (Gejman et al. 1994)). By and large, the association studies are group comparisons, rather than within-family transmission tests. There are many studies whose entire molecular investigation consists of one polymorphism. Even for a negative conclusion, that there is no disease association with any of the genes, the evidence is modest because of the methods used. Also, few sequence variants have been tested for functional differences (such as was done by Cravchik et al. 1996 and Asghari et al. 1994).

Nearly all the studies do not detect association or linkage to these dopamine receptor genes. For dopamine receptor $\mathrm{D}_{2}\left(\mathrm{DRD}_{2}\right)$, we found 12 studies (references omitted for reasons of space). Only one reports nominal significance (Arinami et al. 1994). For $\mathrm{DRD}_{4}$, there are 11 studies, with one (Catalano et al. 1993) having a nominally significant association with delusional disorder but not with schizophrenia. Even taking into account that there could be a very weak effect of one of these genes, the large number of negative studies, with no replication at all of the "positive" reports, implies there is no valid association.

For $\mathrm{DRD}_{3}$, the picture is mixed; a possibly valid weak positive finding might be contained within two reports. An initial study (Crocq et al. 1992) did not find an allelic association with a bi-allelic polymorphism of $\mathrm{DRD}_{3}$, which codes for a serine to glycine amino acid substitution. Further examination of the data suggested a genotypic association with genotype 1-1 $(p<.008)$ and with homozygosity $(p=.0001)$. We were able to find 16 studies of $\mathrm{DRD}_{3}$ association with schizophrenia following the initial publication. Disregarding studies that retrospectively subdivided their sample, or that pooled published with new samples, only one study (Shaikh et al. 1996) replicates the initial finding. This article studies a similar French and English sample to that studied by Crocq et al. and finds an association of schizophrenia with the 1-1 genotype $(p=.003)$, as in Crocq et al., and also an association of illness with allele 1, unlike Crocq. Despite all the nonreplications, it 
would appear worthwhile to do further studies, including molecular scanning of the entire receptor gene in some families, and functional studies of the known variant and others that may be discovered.

\section{Endophenotype Research Strategy of Freedman et al.}

Freedman et al. (1997) studied inheritance of a neurophysiologic abnormality associated with schizophrenia, a defect in the normal decrease of a cortical evoked potential (P50) after repeated auditory stimuli. A genomewide scan of P50 abnormality was done in members of nine schizophrenia pedigrees, without respect to affection status with schizophrenia. Linkage was found to be present, using a single-locus model of the trait, to markers on chromosome 15 , very close to the gene for the $\alpha 7$ subunit of the nicotinic cholinergic receptor.

This receptor was theoretically a candidate gene for this phenomenon, based on basic studies, but the statistical significance of the linkage is based on a genomewide scan, with a nominal $p$-value of .000016 . This work is thus a hybrid of the candidate gene and genomewide scan approaches. It was also innovative in choosing as phenotype not the illness, but a component of the illness that can also be found in well family members. Interestingly, in these families linkage of this chromosomal region to schizophrenia could not be detected by the same markers. If the finding is in fact related to a component of illness, one would expect linkage to illness to be detectable, in a large enough sample.

Several comments can be offered on the study, which do not detract from its importance. Although the relation of P50 and the chromosome 15 region is established by the results, a relationship of the genetic finding to schizophrenia and to the nicotinic cholinergic receptor is only suggested. The receptor subunit gene must be shown to have functional mutations in disequilibrium with the P50 trait to be implicated definitively. Without such evidence, it is possible that the variant responsible for the linkage may in fact be in another nearby gene.

The analysis of the P50 trait does not extract all the information from the measurements in the family members. The trait was collapsed into a qualitative trait, rather than analyzed as a quantitative trait. It may be that the observed variation is, in fact, noise, and that the underlying trait is a binary one, but this has not been investigated.

Other neurophysiological traits can be studied in this manner, such as the oculomotor abnormalities in schizophrenia (Arolt et al. 1996). Risch and Zhang (1996) have developed a very efficient sampling scheme for detecting linkage to one quantitative trait. This consists of finding sib-pairs who are extremely discordant on the trait of interest, and genotyping only them. Because linkage is equivalent to regressing the trait difference on the genetic difference in marker concordance, this gives maximal linkage information per genotyped pair. It is not clear that this scheme can be applied if one is interested in families with both illness and a quantitative trait, because it might be out of the bounds of practicality to do the sampling. For example, one might try to find siblings who have a close relative with schizophrenia and are discordant on oculomotor performance, but it would be a challenge. On the other hand, the oculomotor trait could be sampled directly in a population, and linkage studies of the trait could be done straightforwardly and most efficiently with extreme discordant sib-pairs.

\section{CONCLUSION}

Genetic linkage studies that in retrospect were false starts and nonreplicated results, and that appeared unique to the major psychoses some years ago, have since occurred in other classes of common diseases with complex inheritance. Nonetheless, in manic-depressive illness, as in diabetes mellitus and other traditional medical disorders, linkages have gradually been established. Looking backward in manic-depressive illness and schizophrenia, it appears that advances in the human genetic linkage map, and in the analysis of linkage in complex disease, contributed to the current situation where at least some of the linkage findings have credibility from multiple positive reports. The major psychoses seem destined to exemplify the dictum that by using genome scanning methods "one can systematically discover the genes causing inherited diseases without any prior biological clue as to how they function" (Lander and Schork 1994). Although we believe the positive linkage results represent important progress, we are as yet a long way from demonstrated disease mutations in schizophrenia and bipolar illness.

The other major investigative approach, neuropharmacology-based candidate genes, has been disappointing thus far. The correct statistical analysis of association results when there are many candidates is only now beginning to be developed. This may reduce the unfortunate number of never-reproduced positive reports. Nonetheless, neither the candidate gene approach nor the genome scanning approach has demonstrated unequivocal superiority in these disorders. The development of hybrid genetic investigation strategies, which combine demonstrated pathophysiology with genome scanning, recently implemented by Freedman et al. (1997), is an innovation that may allow us to bypass the "either-or" choice of genetic strategy.

\section{REFERENCES}

Arinami T, Itokawa M, Enguchi H, Tagaya H, Yano S, Shimizu H, Hamaguchi H, Toru M (1994): Association 
of dopamine $\mathrm{D}_{2}$ receptor molecular variant with schizophrenia [see comments]. Lancet 343:703-704

Arolt V, Lencer R, Nolte A, Muller-Myhsok B, Purmann S, Schurmann M, Leutelt J, Pinnow M, Schwinger E (1996): Eye tracking dysfunction is a putative phenotypic susceptibility marker of schizophrenia and maps to a locus on chromosome 60 in families with multiple occurrence of the disease. Am J Med Genet (Neuropsychiat Genet) 67:564-579

Asghari V, Schoots O, van Kats S, Ohara K, Jovanovic V, Guan HC, Bunzow JR, Petronis A, Van Tol HH (1994): Dopamine $\mathrm{D}_{4}$ receptor repeat: Analysis of different native and mutant forms of the human and rat genes. Mol Pharmacol 46:364-373

Badner JA, Goldin LR (1997): Bipolar disorder and chromosome 18: An analysis of multiple data sets. Genetic analysis workshop 10 detection of genes for complex traits (in press)

Bell JI, Lathrop M (1996): Multiple loci for multiple sclerosis (editorial). Nature Genet 13:377-378

Berrettini WH, Ferraro TN, Goldin LR, Weeks DE, DeteraWadleigh S, Nurnberger Jr JI, Gershon ES (1994): Chromosome 18 DNA markers and manic-depressive illness: Evidence for a susceptibility gene. Proc Natl Acad Sci USA 91:5918-5921

Berrettini WH, Ferraro TN, Goldin LR, Detera-Wadleigh SD, Choi H, Muniec D, Guroff JJ, Kazuba DM, Nurnberger Jr JI, Hsieh WT, Hoehe MR, Gershon ES (1997): A linkage study of bipolar illness. Arch Gen Psychiatry 54:27-35

Blackwood DHR, He L, Morris SW, McLean A, Whitton C, Thomson M, Walker MT, Woodburn K, Sharp CM, Wright AF, Shibasaki Y, St. Clair DM, Porteous DJ, Muir WJ (1996): A locus for bipolar affective disorder on chromosome 4p. Nature Genet 12:427-430

Carlsson A, Lindquist M (1963): Effect of chlorpromazine or haloperidol on formation of 3-methoxytyramine and normetanephrine in mouse brain. Acta Pharmacol Toxicol 20:140-144

Catalano M, Nobile M, Novelli E, Nothen MM, Smeraldi E (1993): Distribution of a novel mutation in the first exon of the human dopamine $\mathrm{D}_{4}$ receptor gene in psychotic patients. Biol Psychiatry 34:459-464

Coon H, Hoff M, Holik J, Hadley D, Fang N, Reimherr R, Wender P, Byerley W (1996): Analysis of chromosome 18 DNA markers in multiplex pedigrees with manic depression. Biol Psychiatry 39:689-696

Cooper DN, Schmidtke J (1992): Molecular genetic approaches to the analysis and diagnosis of human inherited disease: An overview. Ann Med 24:29

Copeman JB, Cucca F, Hearne CM, Cornall RJ, Reed PW, Ronningen KS, Undlien DE, Nistico L, Buzzetti R, Tosi R, Pociot F, Nerup J, Cornelis F, Barnett AH, Bain SC, Todd JA (1995): Linkage disequilibrium mapping of a type 1 diabetes susceptibility gene (IDDM7) to chromosome 2q31-q33. Nature Genet 9:80-85

Cordell HJ, Todd JA (1995): Multifactorial inheritance in type I diabetes. Trends Genet 11:499-503

Cravchik A, Sibley DR, Gejman PV (1996): Functional analysis of the human $\mathrm{D}_{2}$ dopamine receptor missense variants. J Biol Chem 42:26013-26017
Crocq MA, Mant R, Asherson P, Williams J, Hode Y, Mayerova A, Collier D, Lannfelt L, Sokoloff P, Schwartz JC (1992): Association between schizophrenia and homozygosity at the dopamine $D_{3}$ receptor gene [see comments]. J Med Genet 29:858-860

Crowe RR (1993): Candidate genes in psychiatry: An epidemiological perspective. Am J Med Genet (Neuropsychiat Genet) 48:74-77

De Bruyn A, Souery D, Mendelbaum K, Mendlewicz J, Van Broeckhoven C (1996): Linkage analysis of families with bipolar illness and chromosome 18 markers. Biol Psychiatry 39:679-688

Detera-Wadleigh S, Badner JA, Goldin LR, Berrettini WH, Sanders AR, Rollins DY, Turner G, Moses T, Haerian H, Muniec D, Nurnberger Jr JI, Gershon ES (1996): Affected-sib-pair analyses reveal support of prior evidence for a susceptibility locus for Bipolar disorder, on 21q. Am J Hum Genet 58:1279-1285

Elston RC (1997): Algorithms and inferences: The challenge of multifactorial diseases (1996 William Allan award address). Am J Hum Genet 60:255-262

Freedman R, Coon H, Myles-Worsley M, Orr-Urtreger A, Olincy A, Davis A, Polymeropoulos M, Holik J, Hopkins J, Hoff M, Rosenthal J, Waldo MC, Reimherr F, Wender P, Yaw J, Young DA, Breese CR, Adams C, Patterson D, Adler LE, Kruglyak L, Leonard S, Byerley W (1997): Linkage of a neurophysiological deficit in schizophrenia to a chromosome 15 locus. Proc Natl Acad Sci USA 94:587-592

Freimer NB, Reus VI, Escamilla MA, McInnes LA, Spesny M, Leon P, Service SK, Smith LB, Silva S, Rojas E, Gallegos A, Meza L, Fournier E, Baharloo S, Blankenship K, Tyler DJ, Batki S, Vinogradov S, Weissenbach J, Barondes SH, Sandkuijl LA (1996): Genetic mapping using haplotype, association and linkage methods suggests a locus for severe bipolar disorder (BPI) at 18q22-q23. Nature Genet 12:436-441

Gejman PV, Ram A, Gelernter J, Friedman E, Cao Q, Pickar D, Blum K, Noble EP, Kranzler HR, O'Malley S (1994): No structural mutation in the dopamine $\mathrm{D}_{2}$ receptor gene in alcoholism or schizophrenia. Analysis using denaturing gradient gel electrophoresis. JAMA 271:204-208

Gershon ES, Hamovit J, Guroff JJ, Dibble E, Leckman JF, Sceery W, Targum SD, Nurnberger Jr JI, Goldin LR, Bunney Jr WE (1982): A family study of schizoaffective, bipolar I, bipolar II, unipolar, and normal control probands. Arch Gen Psychiatry 39:1157-1167

Gershon ES (1995): Recent developments in genetics of bipolar illness. Adv Biochem Psychopharmacol 49:85-98

Gingrich JA, Caron MG (1993): Recent advances in the molecular biology of dopamine receptors. Annu Rev Neurosci 16:299-321

Ginns EI, Ott J, Egeland JA, Allen CR, Fann CS, Pauls DL, Weissenbachoff J, Carulli JP, Falls KM, Keith TP, Paul SM (1996): A genome-wide search for chromosomal loci linked to bipolar affective disorder in the Old Order Amish. Nature Genet 12:431-435

Goldin LR, Chase GA (1997): Improvement of the power to detect complex disease genes by regional inference procedures. Genet Epidemiol (in press)

Goldin LR, Gershon ES, Berrettini WH, Stine OC, DePaulo R, McMahon F, Meyers D, Nothen M, Propping P, Cichon S, 
Fimmers R, Baur M, Albus M, Franzek E, Kreiner R, Maier W, Rietschel M, Baron M, Knowles J, Gilliam C, Endicott J, Gurling H, Curtis D, Smyth C, Kelsoe J (1997): Description of the genetic analysis workshop 10 bipolar disorder linkage data sets. Genetic analysis workshop 10: detection of genes for complex traits (in press)

Greenberg DA, Hodge SE, Vieland VJ, Spence MA (1996): Affecteds-only linkage methods are not a panacea (letter). Am J Hum Genet 58:892-895

Gurling H, Smyth C, Kalsi G, Moloney E, Rifkin L, O’Neill J, Murphy P, Curtis D, Petursson H, Brynjolfsson J (1995): Linkage findings in bipolar disorder [letter]. Nature Genet 10:8-9

Hauser ER, Boehnke M, Guo S-W, Risch N (1996): Affectedsib-pair interval mapping and exclusion for complex genetic traits: Sampling considerations. Genet Epidemiol 13:117-137

Houwen RH, Baharloo S, Blankenship K, Raeymaekers P, Juyn J, Sandkuijl LA, Freimer NB (1994): Genome screening by searching for shared segments: Mapping a gene for benign recurrent intrahepatic cholestasis. Nature Genet 8:380-386

Kruglyak L (1996): Thresholds and sample sizes [letter; comment]. Nature Genet 14:132-133

Kruglyak L, Lander ES (1995): High-resolution genetic mapping of complex traits. Am J Hum Genet 56:1212-1223

Lander E, Kruglyak L (1995): Genetic dissection of complex traits: Guidelines for interpreting and reporting linkage results [see comments]. Nature Genet 11:241-247

Lander ES, Schork NJ (1994): Genetic dissection of complex traits. Science 265:2037-2048

LaSpada AR, Paulson HL, Fischbeck KH (1994): Trinucleotide repeat expansion in neurological disease. Ann Neurol 36:814-822

Losonczy MF, Davidson M, Davis KL (1987): The dopamine hypothesis of schizophrenia. In Meltzer HY (ed), Psychopharmacology: The Third Generation of Progress. New York, Raven Press, pp 715-726

McKusick VA (1994): Mendelian Inheritance in Man: A Catalog of Human Genes and Genetic Disorders. Baltimore, MD, Johns Hopkins University Press

Moises HW, Yang L, Kristbjarnarson H, Wiese C, Byerley W, Macciardi F, Arolt V, Blackwood D, Liu X, Sjöogren B, Aschauer HN, Hwu HG, Jang K, Livesley WJ, Kennedy JL, Zoega T, Ivarsson O, Bui MT, Yu MH, Havsteen B, Commenges D, Weissenbach J, Schwinger E, Gottesman II, Pakstis AJ, Wetterberg L, Kidd KK, Helgason T (1995): An international two-stage genome-wide search for schizophrenia susceptibility genes. Nature Genet 11: 321-324

Nothen M, Cichon S, Craddock N, Albus M, Maier W, Lichtermann D, Weigelt B, Franzek E, Rietschel R, Korner J, Fimmers R, Propping P (1996): Linkage studies of bipolar disorder to chromosome 18 markers [Abstract]. In 39th ed. Chicago, IL, University of Chicago Press, p 615

Nurnberger Jr JI, Goldin LR, Gershon ES (1994): Genetics of psychiatric disorders. In Winokur G, Clayton PJ (eds), The Medical Basis of Psychiatry. Philadelphia, W.B. Saunders, pp 459-492
Ram A, Guedj F, Cravchik A, Weinstein L, Cao Q, Badner JA, Goldin LR, Grisaru N, Manji HK, Belmaker RH, Gershon ES, Gejman PV (1997): No abnormality in the gene for the $G$ protein stimulatory alpha subunit in patients with bipolar disorder. Arch Gen Psychiatry 54:44-48

Rice JP (1997): The role of meta-analysis in linkage studies of complex traits (commentary). Am J Med Genet (Neuropsychiat Genet) 74:112-114

Risch N (1990a): Linkage strategies for genetically complex traits. I. Multilocus models. Am J Hum Genet 46:222228

Risch N (1990b): Linkage strategies for genetically complex traits. II. The power of affected relative pairs. Am J Hum Genet 46:229-241

Risch N, Botstein D (1996): A manic depressive history [news]. Nature Genet 12:351-353

Risch N, Merikangas K (1996): The future of genetics studies of complex human diseases. Science 273:1516-1517

Risch N, Zhang H (1996): Mapping quantitative trait loci with extreme discordant sib pairs: Sampling considerations. Am J Hum Genet 58:836-843

Ross CA, McInnis MG, Margolis RL, Li S-H (1993): Genes with triplet repeats: Candidate mediators of neuropsychiatric disorders. Trends Neurosci 16:254-260

Schizophrenia Linkage Collaborative Group for Chromosomes 3, 6, and 8 (1996): Additional support for schizophrenia linkage on chromosomes 6 and 8: a multicenter study. Am J Med Genet (Neuropsychiat Genet) 67:580594

Schwab SG, Albus M, Hallmayer J, Hönig S, Borrmann M, Lichtermann D, Ebstein RP, Ackenheil M, Lerer B, Risch N, Maier W, Wildenauer DB (1995): Evidence for susceptibility gene for schizophrenia on chromosome $6 \mathrm{p}$ by multipoint affected-sib-pair linkage analysis. Nature Genet 11:325-327

Scott WK, Pericak-Vance MA, Haines JL (1997): Genetic analysis of complex diseases (letter). Science 275:1327

Shaikh S, Collier DA, Sham PC, Ball D, Aitchison K, Vallada H, Smith I, Gill M, Kerwin RW (1996): Allelic association between a Ser-9-Gly polymorphism in the dopamine $\mathrm{D}_{3}$ receptor gene and schizophrenia. Hum Genet 97:714719

Smyth C, Kalsi G, Curtis D, Brynjolfsson J, O’Neill J, Rifkin L, Maloney E, Murphy P, Petursson H, Gurling $\mathrm{H}$ (1997): Two-locus admixture linkage analysis of bipolar and unipolar affective disorder supports the presence of susceptibility loci on chromosomes 11p15 and 21q22. Genomics 39:271-278

Spielman RS, Ewens WJ (1996): The TDT and other familybased tests for linkage disequilibrium and association (invited editorial). Am J Hum Genet 59:983-989

Stine OC, Xu J, Koskela R, McMahon FJ, Gschwend M, Friddle C, Clark CD, McInnis MG, Simpson SG, Breschel TS, Vishio E, Riskin K, Feilotter H, Chen E, Shen S, Folstein SE, Meyers DA, Botstein D, Marr TG, DePaulo JR (1995): Evidence for linkage of bipolar disorder to chromosome 18 with a parent of origin effect. Am J Hum Genet 57:1384-1394

Straub RE, Lehner T, Luo Y, Loth JE, Shao W, Sharpe L, Alexander JR, Das K, Simon R, Fieve RR, Lerer B, Endi- 
cott J, Ott J, Gilliam TC, Baron M (1994): A possible vulnerability locus for bipolar affective disorder on chromosome 21q22.3. Nature Genet 8:291-296

Straub RE, MacLean CJ, O’Neill FA et al. (1995): A potential vulnerability locus for schizophrenia on chromosome 6p24-22: Evidence for genetic heterogeneity. Nature Genet 11:287-293

Suarez BK, Rice JP, Reich T (1978): The generalized sib pair IBD distribution: Its use in the detection of linkage. Ann Hum Genet 42:87-94

Wang S, Sun CE, Walczak CA, Ziegle JS, Kipps BR, Goldin LR, Diehl SR (1995): Evidence for a susceptibility locus for schizophrenia on chromosome 6pter-p22. Nature Genet 10:41-46

Weeks DE, Lange K (1988): The affected-pedigree-member method of linkage analysis. Am J Hum Genet 42:315-326

Wildenauer DB, Hallmayer J, Albus M, Schwab SG, Strauss M, Hoenig S, Borrman M, Lichtermann D, Ackenheil M, Ebstein RE, Trixler M, Lerer B, Maier W (1996): Searching for susceptibility genes in schizophrenia by genetic linkage analysis. In Byers PH (ed), Anonymous Function and Dysfunction in the Nervous System. Cold Spring Harbor, NY, Cold Spring Harbor Laboratory Press 